\title{
Two Types of Legal Wrongdoing
}

\author{
M.E. Newhouse* \\ University of Surrey School of Law \\ 21(3) Legal Theory __ (2015) (forthcoming)
}

There are two distinct types of legal wrongdoing: civil and criminal. This article demonstrates in three ways that Immanuel Kant's Universal Principle of Right, properly interpreted, offers a plausible and resilient account of this important distinction. First, Kant's principle correctly identifies attempted crimes as crimes themselves even when they do not violate the rights of any individual. Second, it justifies our treatment of reckless endangerment as a crime by distinguishing it from ordinary negligence, traditionally thought to be only civilly wrong. Third, it explains and justifies differences between the features of traditional criminal punishments and the features of civil remedies. Moreover, the Universal Principle of Right yields a Kantian standard for criminal wrongdoing that is compelling enough to inform future philosophical inquiries into the nature and limits of the state's criminal lawmaking authority.

\section{Introduction}

Kant presents his Universal Principle of Right as the keystone of his legal philosophy.

Yet despite the principle's apparent centrality, scholars disagree about its meaning. The principle appears to articulate either one standard or two standards according to which actions are "right" in the sense that they are consistent with justice. Single-standard interpretations of the Universal Principle of Right, according to which Kant articulated a unitary standard in two different ways, have recently been popular among Kantian theorists. However, this article demonstrates that no single-standard interpretation of the Universal Principle of Right can adequately account for key distinctions that Kant elsewhere draws between material and formal wrongdoing 1 — distinctions

* I am grateful to Arthur I. Applbaum, Hrafn Asgeirsson, Christopher Essert, Charles Fried, Frances Kamm, Michael J. Kessler, Luke Mason, Zoë Seinel, Daniel Viehoff, Jacob Weinrib, Allen W. Wood, the members of the UK Kant Society, and anonymous reviewers for valuable advice and feedback. I am also grateful to the Edmond J. Safra Center for Ethics at Harvard University for generous financial support. All errors are my own.

1 "This distinction between what is merely formally wrong and what is also materially wrong has many applications in the doctrine of right." IMMANUEL KANT, THE METAPHYSICS OF MORALS 86 (Mary Gregor trans., Cambridge University Press 1996). As is customary, I give page references to the Prussian Academy pagination (Ak. 6:308), for all of Kant's works in addition to the cited translation. 
which, in a civil society, track the familiar legal distinction between civil and criminal wrongdoing. ${ }^{2}$

This article proposes a textually sensitive, two-standard interpretation of the Universal Principle of Right that reflects the two ways in which actions can be legally wrong. I illustrate the plausibility and resilience of Kant's principle as an account of the distinction between civil and criminal wrongdoing in three ways. First, so interpreted, the Universal Principle of Right can correctly identify attempted crimes as crimes themselves even when they do not violate the rights of anyone in particular. Second, it can justify our treatment of reckless endangerment as a crime by distinguishing it from ordinary negligence, which traditionally is only a civil cause of action. Third, it explains and justifies differences between the features of traditional criminal punishments such as incarceration and the features of civil remedies such as monetary or injunctive relief.

Moreover, my proposed interpretation of the Universal Principle of Right includes a novel formulation of Kant's standard for criminal wrongdoing that is normatively compelling enough to inform future philosophical inquiries into the nature and limits of the state's criminal lawmaking authority. One implication of my proposed formulation is that the state lacks the authority to impose criminal penalties for strict liability offenses.

\section{The Universal Principle of Right}

The Universal Principle of Right is central to Kant's legal philosophy. The principle appears to articulate the standard (or standards) according to which actions are just, or "right" (recht). Philosophers have struggled with its awkward and ambiguous language. In Mary Gregor's popular English translation of The Metaphysics of Morals, the Universal Principle of Right states:

Any action is right if it can coexist with everyone's freedom in accordance with a universal law, or if on its maxim the freedom of choice of each can coexist with everyone's freedom in accordance with a universal law. ${ }^{3}$

So translated, the principle appears to offer two separate standards according to which actions are right, but this is a contested point. ${ }^{4}$ Many Kantians read the principle as articulating a single standard for right conduct, in which Kant simply chose to rephrase a portion of his principle.

2 "A transgression of public law that makes someone who commits it unfit to be a citizen is called a crime (crimen) simply but is also called a public crime (crimen publicum); so the first (private crime) is brought before a civil court, the latter before a criminal court." Id. at 105. (Ak. 6:331)

${ }^{3} I d$. at 24. (Ak. 6:230)

${ }^{4}$ Gregor's translation may exaggerate the principle's appearance of articulating two standards because it features a compound sentence form not found in the original German text. See infra 
Unitary readings of the Universal Principle of Right have lately predominated. Influential Kantians have sometimes even truncated Gregor's translation, eliminating language suggesting the possibility of two standards. For example, Arthur Ripstein writes, "The universal principle of right characterizes an action as right 'if it can coexist with everyone's freedom in accordance with a universal law'." Allen W. Wood similarly holds that "[A]ctions are right only if they can coexist with everyone's freedom under this system according to a universal law." Summaries like these imply that the principle's omitted language creates more confusion than illumination.

If the principle should be read to articulate one standard rather than two, it must be the case that the words that translate to "if [the action] can coexist" (die... kann bestehen) can be understood to have the same meaning as the words that translate to "if on [the action's] maxim the freedom of choice of each can coexist" (nach deren Maxime die Freiheit der Willkür eines jeden ...kann bestehen). See Figure 1. Ideally, it should also be possible to identify a reason why Kant would have chosen to articulate a portion of his Universal Principle of Right in two different ways.

\section{Figure $1^{7}$}

\section{Universal Principle of Right:}

Any action is right if it can coexist with everyone's freedom in accordance with a universal law, Or if on its maxim the freedom of choice of each can coexist with everyone's freedom in accordance with a universal law. (Gregor 1991)

Eine jede Handlung ist recht, die odernach deren Maxime die Freiheit der Willkür eines jeden mit jedermanns Fréiheit nach éinem allgemeinen Gesetze zusammen bestehen kann. (Kant 1798)

Figure 1. German grammatical conventions "permit much more unity" between the word that is translated to "action" and the phrase that is translated to "on its maxim the freedom of choice of each" than Gregor's translation suggests. Interview with Marcus Wilczek, Assistant Professor of Germanic Languages and Literatures, Harvard University (Feb. 14, 2012). Indeed, this word and phrase appear right next to each other in the original German, and the words that translate to "coexist with everyone's freedom in accordance with a universal law" only appear once, near the end of the sentence. See infra Figure 1.

${ }^{5}$ Arthur Ripstein, Means and Ends, 6 JURISPRUDENCE 1, 8 (2015).

${ }^{6}$ Allen W. Wood, Kantian Ethics 243 (2008).

${ }^{7}$ KANT, supra note 1, at 24. (Ak. 6:230); IMMANUEL KANT, DiE METAPHYSIK DER SitTEN (1798). 
Regarding Kant's motivation to rephrase, Ripstein offers that Kant may have rephrased a principle about actions in terms of maxims because maxims enable us to individuate actions. ${ }^{8} \mathrm{He}$ means that one cannot identify a distinct action in the context of an agent's ongoing activities except by reference to the agent's maxim, because a maxim adopts specific means (e.g. "walk across the field") to further a chosen end (e.g. "to see the sunset over the ocean"). Ripstein's explanation seems plausible at first, because his point that maxims enable us to individuate actions is correct.

However, this explanation does not account for Kant's inclusion of the additional words, "the freedom of choice of each" (Freiheit der Willkür eines jeden) in what Ripstein considers Kant's restatement of his unitary principle. Kant's second clause does not merely ask whether my action, uniquely picked out by my maxim, can itself coexist with everyone's freedom in accordance with a universal law. It asks whether "on [the action's] maxim the freedom of choice of each can coexist with everyone's freedom in accordance with a universal law."

Textually, it makes more sense to understand these words as follows: Can the freedom of each person to choose to act on my maxim coexist with everyone's freedom in accordance with a universal law? More briefly: Could everyone be free if acting on my maxim were legal? My twopronged interpretation of the Universal Principle of Right can therefore be summarized like this:

Any action A is right 1) if A can coexist with everyone's freedom in accordance with a universal law, or 2) if the legality of actions on A's maxim can coexist with everyone's freedom in accordance with a universal law.

The first prong articulates, in inverse form, Kant's standard for material wrongs: "Any action is right if it can coexist with everyone's freedom in accordance with a universal law." Material wrongs involve actions that, as Ripstein points out, are individuated by their maxims. Nonetheless, I will show that Ripstein's work elsewhere proves that maxims are otherwise irrelevant to whether an action is a material wrong. It is possible to commit a material wrong by acting on an entirely innocent maxim. An action fails to be right under this standard if it is physically incompatible with the freedom of others.

The second prong of the Universal Principle of Right articulates, in inverse form, Kant's standard for formal wrongs: "Any action is right...if on its maxim the freedom of choice of each can coexist with everyone's freedom in accordance with a universal law." I take Kant to mean that any action $\mathrm{A}$ is right if the legality of actions on A's maxim (i.e. the "freedom of choice of each" to act "on its maxim") could coexist with everyone's freedom in accordance with a universal law. In the context of Kant's legal and political writings, "a universal law" refers

\footnotetext{
${ }^{8}$ Ripstein writes, "What I $d o$ is individuated by my maxim". ARTHUR RIPSTEIN, FORCE AND FREEDOM: KANT's LEGAL AND POLITICAL PHILOSOPHY 381 (2009).

${ }^{9}$ KANT, supra note 1, at 24. (Ak. 6:230) (italics added)
} 
roughly to the idea of a set of laws that establishes a just political order, a circumstance that Kant refers to as a "rightful condition". This standard compares two concepts: 1) the legality of actions on the maxim in question, and 2) the idea of everyone's freedom in a just political order. Therefore, an action will fail to meet this just in case these two concepts are incompatible. ${ }^{10}$

In the pages that follow, I argue that the distinctions that Kant draws elsewhere between civil and criminal wrongdoing are inconsistent with the possibility of a unitary interpretation of the Universal Principle of Right. Instead, the principle must establish two standards that track these two different ways in which actions can be legally wrong. This is the case because, as I will illustrate, the wrong-making property of a materially (and therefore civilly) wrong action is a property of the action's outer form - its physical manifestation - while the wrong-making property of a formally (and therefore criminally) wrong action is a property of the action's principle of inner determination-its maxim.

\section{Material Wrongs}

In Kantian terms, material wrongs are actions that are physically incompatible with the rights of one or more individuals. Because a rightful condition (i.e. a condition of living under "a universal law") requires my possible choices and your possible choices to be consistent with each other, the law must establish procedures that enable us to acquire rights of property, contract, and status. ${ }^{11}$ The sum of what is rightfully yours-your person as well as any acquired rights of property, contract, or status - constitutes the means that you have at your disposal when you exercise your free agency by choosing your ends.

Ripstein observes that I can materially wrong you in two possible ways: I can interfere with your use of what is yours, or I can use what is yours without your authorization. The exact nature of this second kind of material wrongdoing can be hard to pin down, because the victim is often unharmed and may even be unaware that she was wronged. For example, a stranger who touches you while you sleep wrongs you, even though he does not harm you. Ripstein explains what is wrong with touching a sleeping person in this way: "the person who touches you without your authorization uses you for a purpose that is his but not yours." 12

Because using someone else's person or property is a material wrong unless a certain kind of mutual intent - authorization - makes the use rightful, one person can wrong another by accident if she fails to realize that she is using something that belongs to someone else. Ripstein

\footnotetext{
${ }^{10}$ Negation, is the only kind of incompatibility that can exist between two concepts. See Immanuel Kant, Critique of Pure Reason, in THE CAMBRIDGE EDITION OF THE WORKS OF ImMANUEl Kant: CRITIQUe OF PURE REASON Vol. II 369 n.a (Paul Guyer \& Allen W. Wood trans., Cambridge University Press 1998). (A265/B321)

${ }^{11}$ See RIPSTEIN, supra note 8, at 57-60.

12 RIPSTEIN, supra note 8, at 47.
} 
explains that the tort of innocent trespass is an example of a wrong that no one undertakes to commit. ${ }^{13}$ I may intend to build a tree house on my own property, but because I misread my map, I mistakenly build it on your land instead. I have thereby wronged you even though I had no idea that the land on which I built my tree house was yours.

Just as bad intentions are not necessary to make an act materially wrong, they are not sufficient. One person may try to wrong another and yet fail to do so. For example, suppose that Richard decides to prevent Edward from interviewing for a job that Richard wants. He plans to accomplish this by stealing the spark plugs from Edward's car, so that Edward cannot drive to the interview. Edward gets lucky, however, because the two men own identical black Mustangs. Richard misreads his own license plate in the dark and mistakenly removes the spark plugs from his own car rather than Edward's car. Despite Richard's best efforts, he has not wronged Edward. He has not interfered with Edward's use of his car, nor has he used - or even touchedEdward's spark plugs without permission, but that does not mean that Richard has not acted wrongly at all. I will show that crimes of attempt, such as Richard's attempted theft, are formal wrongs.

\section{Formal Wrongs}

Formal wrongs are not, per se, wrongs against other individuals, although they may also involve material wrongdoing. Rather, formal wrongs violate "the right of human beings as such" to live in a rightful condition. In the context of an existing state, Kant refers to formal wrongs as "public crimes." 14 A public crime is "a transgression of public law that makes someone who commits it unfit to be a citizen... because they endanger the commonwealth and not just an individual citizen." 15

Formal wrongs require a type of intentionality that material wrongs do not, which is reflected in the maxim of the action. ${ }^{16}$ Any "deed contrary to duty is called a transgression,"category that includes both material and formal wrongs - but an "unintentional transgression which can still be imputed to an agent is a mere fault." "The tort of innocent trespass, which I committed when I mistakenly built my tree house on your property, is an example of a "mere fault." Material wrongs "can still be imputed to the agent" in a civil lawsuit if they are innocently committed, but such mistakes are not crimes, because their maxims_-for example, "I will build a

\footnotetext{
${ }^{13}$ See Arthur Ripstein, As If It Had Never Happened, 48 WILlIAM \& MARY LAW REVIEW 1957, 1991 (2007).

${ }^{14}$ KANT, supra note 1, at 105. (Ak. 6:331)

15 Ibid.

${ }^{16}$ Onora O’Neil has shown that maxims must include act descriptions. See ONORA O'NeIL, ACting ON A PRINCIPLE: AN ESSAY ON KANTIAN ETHICS 12-31 (1975).

${ }^{17}$ KANT, supra note 1, at 16. (Ak. 6:224) (Latin parenthetical omitted)
} 
tree house on my property in order to amuse my children"- -are unobjectionable. ${ }^{18}$ As Kant writes, a material wrong "does not always presuppose that there is in the subject a principle for [a wrongful] act."19

By contrast, "an intentional transgression (i.e., one accompanied by consciousness of its being a transgression) is called a crime." ${ }^{20}$ In the state of nature, it is "willing to be and to remain in" a non-rightful condition that is formally wrong. ${ }^{21}$ Remaining in the state of nature because you can't figure out how to exit it is merely unfortunate. In the common law tradition, a "guilty mind"-mens rea - is analogously a traditional element of a crime. Kant explains that a common criminal can be distinguished from an anarchist by the different maxims on which they act, but that both commit formal wrongs. ${ }^{22}$ If my proposed interpretation of the Universal Principle of Right is correct, this is the case because the legality of actions on the maxim of either of these wrongdoers is conceptually incompatible with the idea of a rightful condition.

A common criminal merely "deviates from the law (although intentionally)" by making herself an exception to it. ${ }^{23}$ She might act on the maxim: "I will steal from others in order to increase my wealth." Such a criminal does not wish to live in a lawless condition. Indeed, her purpose of increasing her own wealth presupposes the security of her own rights even as she violates the rights of others. When she acts on her maxim, she commits a formal wrong because the legality of theft is conceptually incompatible with the idea of everyone's freedom in accordance with a universal law. This is the case because coercive enforcement is a constitutive element of any property right, and the concept of property rights is contained in the concept of a rightful condition. ${ }^{24}$

The anarchist, by contrast, "rejects the authority of the law itself" because he does not count on the continued obedience of others in order to remain secure in his own rights. ${ }^{25} \mathrm{He}$ might act on the maxim, "I will use deadly force in order to defend myself from police officers

\footnotetext{
${ }^{18}$ Ibid.

${ }^{19}$ Immanuel Kant, On a Supposed Right to Lie Because of Philanthropic Concerns, in (Ak. 429)

${ }^{20}$ KANT, supra note 1, at 16. (Ak. 6:224) (Latin parenthetical omitted)

${ }^{21}$ Id. at 86. (Ak. 6:307-8) (emphasis added)

${ }^{22} I d$. at 97. (Ak. 6:320) (footnote)

${ }^{23}$ Ibid.

${ }^{24}$ See id. at 40-2. (Ak. 6:246-252)

${ }^{25} I d$. at 97. (Ak. 6:320) (footnote)
}

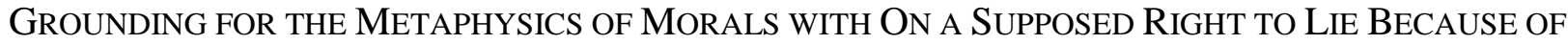
Philanthropic Concerns 67 (James W. Ellington, ed., Hackett Publishing Co. 3rd ed. 1993). 
who try to arrest me," fully acknowledging that others may do the same, and perhaps hoping that they will. When the anarchist acts on his maxim, he commits a formal wrong nonetheless, because according to Kant's a priori derivation of the state's necessary powers, "the executive power of the supreme ruler is irresistible." 26 This is a conceptual rather than empirical claim-it may be physically possible to resist executive branch officials, but it is not legally possible to do so in a rightful condition. ${ }^{27}$ The legality of coercion of executive branch officials is incompatible with the concept of a rightful condition because the latter contains the idea of the irresistible coercive power of the executive. This is why it is a crime to resist arrest.

The above examples focus on formally wrong actions that also violate the rights of individuals to property or physical safety, and therefore happen to be material wrongs as well. But not all formal wrongs are material wrongs. For example, Kant acknowledges that an action "which avoids [wronging an individual] only by accident can also be condemned as wrong even by external laws." ${ }^{28}$ In passing, Ripstein likewise suggests that criminal attempts—-such as attempted murder or attempted theft - may be crimes even when perpetrators do not succeed in violating anyone's individual rights. ${ }^{29}$ On my interpretation of the Universal Principle of Right, such attempts are formal wrongs because the legality of actions on the maxim of an attempted crime is incompatible with the concept of a rightful condition.

For example, suppose that the above-mentioned anarchist is nearsighted. When the police arrive, the anarchist mistakenly picks up his child's bubble gun rather than his firearm, points it at the police, and pulls the trigger. Only bubbles emerge from the gun, and even the bubbles don't hit the arresting officers. Assuming that the officers either do not see the gun or immediately recognize it as a toy (otherwise gun wielding may be a tortious threat), the anarchist's action is not a material wrong. Nonetheless, his attempted homicide is a "public crime" because his maxim is identical to what it would have been if he had actually shot the officers.

Richard's failed attempt to prevent Edward from interviewing for a job by stealing Edward's spark plugs is likewise a formal wrong. ${ }^{30}$ Richard accidentally removed his own spark plugs instead, so he did not succeed in wronging Edward. He nonetheless committed the crime of attempted theft because, in Kant's words, Richard failed to wrong Edward "only by accident." 31 The maxim on which Richard acted was just what it would have been had he

${ }^{26}$ Id. at 93. (Ak. 6:316)

${ }^{27}$ RIPSTEIN, supra note 8, at 314.

${ }^{28}$ Kant, supra note 19, at 65. (Ak. 426-7)

${ }^{29}$ Ripstein writes, "If I attempt to wrong you but fail, I may commit a crime, but (unless your apprehension of a battery makes my act an assault) I do not commit a private wrong against you." RIPSTEIN, supra note 8, at 374. (footnote)

${ }^{30}$ See supra Part III.

${ }^{31}$ Kant, supra note 19, at 65. (Ak. 426-7) 
succeeded: "I will steal Edward's spark plugs in order to prevent him from interviewing for the job I want." Richard's action was formally (and therefore criminally) wrong because the legality of spark plug theft (or any theft) is incompatible with the concept of a rightful condition.

On my proposed interpretation of the Universal Principle of Right, Kant's standard for formal, and therefore criminal, wrongdoing enables us to explain why such attempts must be crimes themselves in a just state, even when they do not violate anyone's rights. The proposed interpretation can likewise explain why ordinary negligence is only a tort (a kind of civil wrong), while reckless endangerment is both a tort and a crime.

\section{Negligence and Recklessness}

Ordinary negligence and reckless endangerment are both torts - a recognized type of civil wrong - in cases in which these acts deprive others of their means. ${ }^{32}$ However, reckless endangerment is also a recognized crime, while ordinary negligence traditionally is not. ${ }^{33}$ In this case, as well, the incompatibility of the legality of actions on a reckless agent's maxim with the concept of a rightful condition best explains why the law regards reckless endangerment as a crime.

Ordinary negligence is not formally wrong because a merely negligent agent acts on unobjectionable maxims. For example, a philosopher might act on the maxim: "I will drive to the store to get some milk." On the way, she might be distracted by thoughts about metaethics, fail to notice a red light, and hit another vehicle. On my proposed interpretation of the Universal Principle of Right, the distracted philosopher has not committed a formal wrong because the legality of actions on her maxim is not incompatible with the concept of a rightful condition.

Nonetheless, the distracted philosopher is civilly liable for the accident, because the law must secure our access to our means by legally enforcing an affirmative standard of reasonable care in situations in which we causally interact with each other. To accomplish this, the civil law traditionally holds negligent actors responsible only for the foreseeable results of their negligence. ${ }^{34}$ This limitation reflects the fact that absent-minded tortfeasors are liable only in virtue of what they failed to do: pay adequate attention. ${ }^{35}$ Because an "unforeseeable" harm just is a harm that one cannot undertake to avoid, unforeseeable harms caused by negligent actions

\footnotetext{
32 Restatement (Third) of Torts $\$ 2-3$ (2010).

${ }^{33}$ Reckless endangerment is a crime in many jurisdictions. See MODEL PENAL CodE $§ 211.2$ (1985).

${ }^{34}$ See, e.g., Palsgraf v. Long Island R.R. Co., 248 N.Y. 339, 344 (N.Y. 1928) ("The risk reasonably to be perceived defines the duty to be obeyed.").

35 "A person acts negligently if the person does not exercise reasonable care under all the circumstances.” RESTATEMENT (THIRD) OF TORTS $§ 3$ (2010).
} 
are harms, but not wrongs. Imposing civil liability on merely negligent individuals for unforeseeable harms would burden our freedom to go about the ordinary activities of life.

By contrast, an act of reckless endangerment is a crime because the danger that these acts create is intentional, and is therefore included in the content of their maxims. ${ }^{36}$ For example, Bluto might act on the maxim, "I will drive through town blindfolded in order to gain admission to a fraternity." Endangering pedestrians is not a purpose for which Bluto acts, but he knows perfectly well that danger to pedestrians is part-and-parcel of his chosen action. The legality of actions on Bluto's maxim is thus incompatible with the concept of a rightful condition, because security in our private rights is constitutive of our freedom. It is because acts of reckless endangerment are formally (and therefore criminally) wrong that they traditionally entail civil liability for unforeseeable losses as well as for foreseeable ones. ${ }^{37}$ Imposing civil liability for unforeseeable losses resulting from a criminal act does not burden freedom, because committing a crime is not something that anyone has a right to do.

\section{Remedies and Punishments}

In addition to illuminating the distinction between criminally and civilly wrong conduct, my proposed interpretation of the Universal Principle of Right can show why criminal punishments have different features than civil remedies. As I have shown, material and formal wrongs have different natures. The wrong-making property of a material wrong is a property of the wrongdoer's physical action: her unauthorized use of (or interference with) someone else's means. By contrast, the wrong-making property of a formal wrong is a property of the maxim on which the wrongdoer acts: the incompatibility between the legality of actions in accordance with that maxim and the concept of a rightful condition.

The state must therefore respond to these two different types of wrongs in different ways. As Kant observes, material wrongs are remedied in civil court, while formal wrongs are punished in criminal court. ${ }^{38}$ The way in which remedies and punishments are analogous but distinct can

\footnotetext{
36 "A person acts recklessly in engaging in conduct if: (a) the person knows of the risk of harm created by the conduct or knows facts that make the risk obvious to another in the person's situation..." Id. at $\$ 2$ (2010). See also O’NEIL, supra note 16, at 12-31.

37 " An actor who intentionally or recklessly causes harm is subject to liability for a broader range of harms than the harms for which that actor would be liable if only acting negligently." Id. at $\S$ 33 (2010).

${ }^{38}$ Kant writes, "A transgression of public law that makes someone who commits it unfit to be a citizen is called a crime (crimen) simply but is also called a public crime (crimen publicum); so the first (private crime) is brought before a civil court, the latter before a criminal court." KANT, supra note 1 , at 105. (Ak. 6:331)
} 
be understood with the help of Kant's discussion of the concepts of opposition and negation in the Critique of Pure Reason. ${ }^{39}$

Kant describes physical opposition as the relation between two opposing forces which, acting on the same object, "partly or wholly destroy the consequence of the other, like two moving forces in the same straight line that either push or pull a point in opposed directions." 40 In a game of tug-of-war, for example, if I pull the rope East with the same force that you pull it West, no net physical movement will result, but our activity of pulling continues to exist (which will be clear to us as it tires us out). In Private Wrongs, Ripstein offers a compelling Kantian analysis of civil damages rules, which he demonstrates approximate this kind of opposition. ${ }^{41}$ To illustrate, the simplest kind of remedy for a material wrong is a court order that physically restores a person's external means to them: a civil court may require a squatter to leave my property or a thief to return something that she has stolen.

Elsewhere, Ripstein suggests that this kind of opposition is always adequate to rectify legal wrongs because he appears to believe that legal wrongs generate exclusively physical incompatibilities in need of rectification. ${ }^{42}$ The physical opposition model makes sense as an account of how to remedy material wrongs, which are indeed physical. By contrast, because I have shown that the incompatibility between formal wrongdoing and everyone's freedom under a universal law is conceptual rather than physical, I propose that just punishments for formal wrongs must negate those wrongs rather than physically oppose them. My interpretation of Kant's Universal Principle of Right is more plausible in light of the fact that traditional criminal punishments approximate negation considerably more closely than they approximate physical opposition.

Criminal punishments such as prison or the death penalty do not restore to victims any money or property of which they may have been deprived. Instead, they re-establish the authority of the state, which is why criminal prosecutors represent the state rather than any private party. A criminal wills a maxim according to which she is free to hinder the freedom of others. A punishment that makes it the case that others are free to hinder the criminal's freedom - through prison or execution, say - inverts this maxim and therefore approximates a negation of the criminal wrong. Kant's description of criminal punishment accords with this implication:

\footnotetext{
${ }^{39}$ Kant, supra note 10 , at 369. (A265/B321)

${ }^{40}$ Kant, supra note 10, at 369. (A265/B321)

41 See generally ARTHUR RIPSTEIN, PRIVATE WRONGS (2016).

42 Ripstein refers to Kant's analysis of the concept of opposition to make a claim about the difference between external freedom and morality. RIPSTEIN, supra note 8, at 376. In the course of this discussion, Ripstein appears to suppose that all wrongs are rectified by means of real opposition - a supposition at odds with my claim here that because formal wrongs are wrong in virtue of the fact that they give rise to conceptual incompatibilities, they can only be rectified by means of negation.
} 
"[W]hatever undeserved evil you inflict upon another within the people, you inflict upon yourself." 43

Kant elsewhere suggests that a retributive standard must be applied by a criminal court, which cannot rightfully "inflict whatever punishments [it] chooses" because such discretion "would be literally contrary to the concept of punitive justice." Universal Principle of Right is philosophically correct rather than merely historically accurateif this is actually the right way to think about the differences between civil and criminal wrongdoing - then recognizing criminal punishment as a kind of negation may bolster the case for continuing to impose physically coercive criminal punishments rather substituting civil remedies for them.

\section{Two Types of Legal Wrongdoing}

I have argued that Kant's Universal Principle of Right establishes two separate standards for the rightness of actions. In support of this argument, I have shown that my proposed standards track the two types of wrongdoing — material and formal — that Kant identifies in his legal and political writings. I have shown that not all material wrongs are formal wrongs, and that not all formal wrongs are material wrongs. ${ }^{45}$ I have also shown that the wrong-making property of a materially wrong action is a property of its "outer form" - the physical act. By contrast, the wrong-making property of a formally wrong action is a property of its "principle of inner determination"-its maxim. I have proposed that an action is a formal wrong just in case the legality of actions on its maxim is incompatible with the concept of a rightful condition.

Figure 2

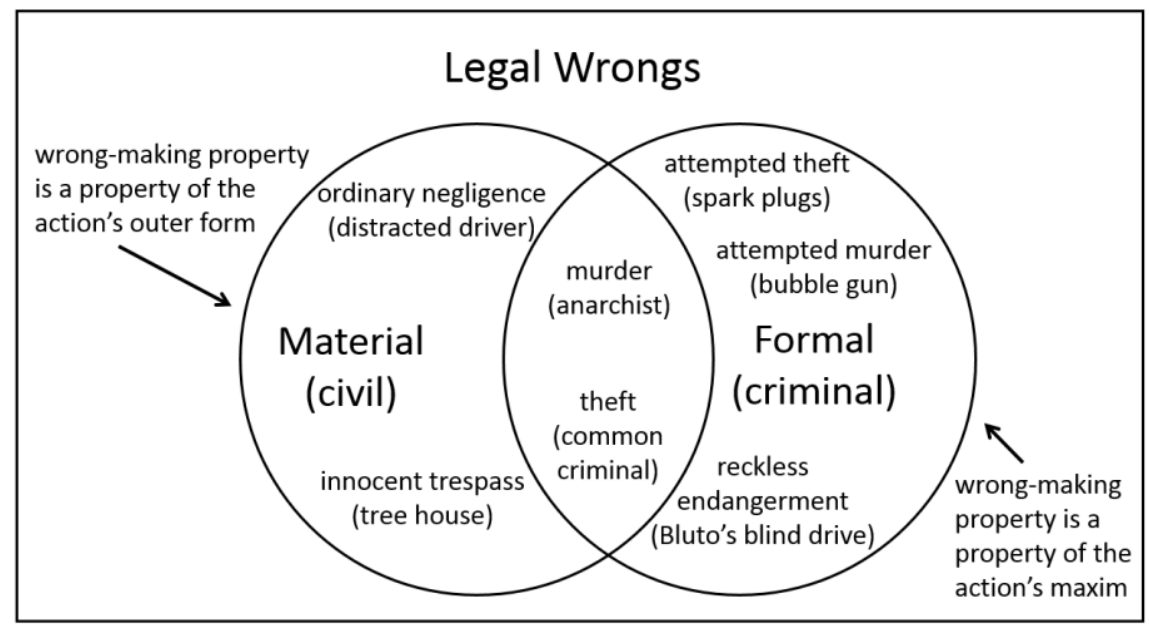

${ }^{43}$ KANT, supra note 1, at 105. (Ak. 6:332)

${ }^{44}$ KANT, supra note 1, at 130. (Ak. 6:363)

45 See Figure 2. 
If the foregoing analysis is sound, it is very unlikely that Kant intended to articulate a single standard for the rightness of actions in the Universal Principle of Right. What single standard could identify both physical and conceptual incompatibilities, or could otherwise correctly determine the contents to two only partially overlapping sets of wrong actions? If a unitary interpretation appears to accomplish either goal, it does so only by using ambiguous language that must be interpreted in two different ways in order to plausibly identify these different types of wrongs.

Consider one of Ripstein's formulations:

The universal principle of right demands that each person exercise his or her choice in ways that are consistent with the freedom of all others to exercise their choice. ${ }^{46}$

In the context of material wrongs, Ripstein's formulation can be interpreted in a way that makes sense: I may not "choose" to use my body or property in "ways" that are physically inconsistent with everyone else's freedom to choose what they will do with theirs. Physical coercion, trespass, theft, and property destruction are all ways of using my body that would be wrong under this test. By specifying that the consistency in question is physical, this reading of Ripstein's test takes the word "ways" to refer to my physical manner of engaging with my means, which may in turn interfere with your means.

This interpretation is plausible in part because it correctly establishes the wrongful nature of torts such as innocent trespass, which are committed mistakenly on the basis of an unobjectionable maxim. The sense in which I "choose" to use my means in these wrongful "ways" is that I choose to engage in the physical action that constitutes the material wrong. The word "choose" does not reflect any knowledge that my act constitutes a transgression. My wrong action is, as Ripstein points out, individuated by my maxim, but my maxim is otherwise irrelevant.

So understood, however, Ripstein's proposed interpretation cannot correctly classify attempted crimes as formal wrongs. Recall Richard's attempted theft of Edward's spark plugs: he undertakes to steal the spark plugs from Edward's car in order to prevent the latter from interviewing for a job that Richard wants. However, Richard mistakenly removes the spark plugs from his own car instead. If the "way" in which Richard uses his means is understood to be his physical engagement with his own spark plugs, it is difficult to see how that physical engagement itself could be wrong. Suppose that Richard removed his own spark plugs because he is prone to sleepwalking and wanted to guard against the possibility of a dangerous, involuntary midnight drive. Although his physical engagement with his means would be identical, Richard's action would not be wrong.

${ }^{46}$ RIPSTEIN, supra note 8, at 35-6. 
But the wrongful nature of Richard's attempted crime can't be located in the referent of the word "choose" either, because we have already determined that this test as applied to material wrongs only understands the word "choose" to require that a particular activity was an action at all. The requirement that I "choose" to use my means in a particular way is satisfied in the case of innocent trespass just so long as, for example, my physical activity of building a tree house qualifies as an action. "Choose" can't denote knowledge of the wrongfulness of an action when the test applies to formal wrongs while denoting no such thing when the same test applies to material wrongs. Not if this test is truly a single standard.

Those who believe that the Universal Principle of Right articulates a single standard might be misled by the "universal law of right," which Kant offers only three paragraphs later. It is tempting to try to read this "universal law of right" as a restatement of the Universal Principle of Right. ${ }^{47}$ But as Mulholland observes, the grammatical form of the Universal Principle of Right is descriptive; it simply identifies the conditions under which an action is right. ${ }^{48}$ By contrast, the "universal law of right" has an imperative form: "so act externally that the free use of your choice can coexist with the freedom of everyone in accordance with a universal law."

Moreover, the German words Prinzip (translated as "principle" in the Universal Principle of Right) and Rechtsgesetz (translated to "law" in the "universal law of right") do not have identical meanings. A "principle," for Kant, need not be a practical (i.e. prescriptive) principle. Kant's "principles of pure understanding" in Critique of Pure Reason, for example, are rules for cognition, not rules for action. ${ }^{50}$ By contrast, the word Rechtsgesetz combines the German word for "law" (Gesetz) with the German word for "right" (Recht). It is consistent with the imperative form of the "universal law of right" to conclude that Kant is using this word specifically to denote a practical law-a law of action. ${ }^{51}$

This distinction matters, because while a juridical law can't require us to adopt any particular maxim, it can prospectively constrain our actions only by constraining the set of maxims on which we may act. Mary Gregor explains:

Since juridical laws require that certain actions take place, they must require that we have certain maxims, because human action is action on a maxim. They do not require that we adopt the formal maxim of lawfulness

\footnotetext{
${ }^{47}$ KANT, supra note 1, at 24-5. (Ak. 6:231)

48 Leslie A. Mulholland, Kant’s System of Rights 168-9 (1990). Accord Allen W. WoOd, KANT 144 (2005).

${ }^{49}$ KANT, supra note 1, at 24-5. (Ak. 6:231)

${ }^{50}$ Kant, supra note 10, at p. 388. (A301/B357)

${ }^{51}$ Kant considers practical laws to be a subset of principles: "A principle that makes certain actions duties is a practical law." KANT, supra note 1, at 17. (Ak. 6:225)
} 
but only that the material maxims which we have be such that we can act upon them without violating the freedom of others. ${ }^{52}$

A practical law of right must therefore command us not to act on criminal maxims. In other words, it must command us not to commit formal wrongs. With this in mind, Kant's "universal law of right" - "so act externally that the free use of your choice can coexist with the freedom of everyone in accordance with a universal law" - commands us to adopt only maxims of action (i.e. principles of choice) that can be legally chosen in a rightful condition. The rest of Kant's sentence explains that the juridical law enforces this command externally.

The "universal law of right" is unitary because it cannot and does not address itself to unintentional wrongs. To command a person not to do something is just to command her not to act on certain maxims, and unintentional wrongs may have irreproachable maxims. The Universal Principle of Right, by contrast, articulates two standards because actions can be wrong in two ways, one of which does not depend on whether an agent undertakes to do wrong.

If this is correct, then Kant restates only the second part of the Universal Principle of Right in imperative form as the "universal law of right." A side-by-side textual comparison supports this reading. The second prong of the Universal Principle of right provides:

Any action is right...if on its maxim the freedom of choice of each can coexist with the freedom of all in accordance with a universal law. ${ }^{53}$

The "universal law of right" provides:

[S]o act externally that the free use of your choice can coexist with the freedom of everyone in accordance with a universal law. ${ }^{54}$

These clauses each refer to the "freedom of choice of each" or the "free use of your choice" rather than to a choice or action, simpliciter. I believe that Kant chose these words because his standard for formal wrongs focuses on whether the legality of actions on some contemplated maxim - the legal freedom to choose to act on that maxim — is conceptually compatible with everyone's freedom in accordance with a universal law.

\footnotetext{
${ }^{52}$ Mary J. Gregor, The Laws of Freedom: A Study of Kant's Method of ApPlying the CATEGORICAL IMPERATIVE 41 (1963). Gregor's meaning would have been clearer if she had put the word "only" in between "have" and "certain" in the first sentence. Her subsequent sentence makes it clear that she means that the set of possible lawful maxims is restricted by the juridical law, and not that the juridical law can require us to adopt a specific maxim.

${ }^{53}$ KANT, supra note 1 , at 24. (Ak 6:230)

${ }^{54}$ Ibid. (Ak 6:231)
} 


\section{Understanding Kant's Disjunctive Principle}

One textual objection to my proposed interpretation of the Universal Principle of Right remains: the principle as written establishes a disjunctive standard for the rightness of actions, when it intuitively seems as though a conjunctive standard is required. Gregor correctly converts the German oder into "or" in her popular translation:

Any action is right if it can coexist with everyone's freedom in accordance with a universal law, or if on its maxim the freedom of choice of each can coexist with everyone's freedom in accordance with a universal law. ${ }^{55}$

Given how I have interpreted its component parts, this principle appears to state that any action is right 1) if it is not a material wrong, "or" 2) if it is not a formal wrong. The worry arises because Kant cannot mean to say that an action which meets either standard is thereby right overall. In order to be right overall, an action must meet both standards. ${ }^{56}$

One possible resolution of this worry is to conclude that the German word oder in this sentence is a scrivener's error-an incorrect word introduced inadvertently, perhaps as a result of repeated redrafting. This hypothesis is made more plausible than it otherwise might be by research suggesting that the Doctrine of Right was poorly edited. ${ }^{57}$ However, an alternative reading based on the central insight of this article may supply a better explanation for the principle's disjunctive form.

The Universal Principle of Right makes sense as written - it is entirely assertable - if we understand Kant to be emphasizing my very thesis: actions can be right in two different ways, corresponding to the two familiar types of legal wrongdoing that this article has described. On this reading, when Kant writes that "Any action is right...", he means to refer to either of the two

${ }^{55}$ Ibid. (Ak. 6:230) (emphasis added)

${ }^{56}$ Logicians have identified two distinct meanings of "or," known as the "inclusive or" and the "exclusive or," but neither one can rescue this sentence as a claim about the overall rightness of actions. If this sentence employs the "inclusive or," it states that any action is right if it meets either one of the two standards. See Alan Hausman, ET AL., LOGIC AND PHILOSOPHY: A MODERN INTRODUCTION 30-2 (12th ed. 2013). A "right action," on this interpretation, also may - but does not need to - meet both standards. The "exclusive or" interpretation also fails to yield the required meaning. Indeed, it is a less plausible choice than the "inclusive or," because the "exclusive or" presupposes that any action which meets one of the two disjunctive standards for rightness must fail the other. Ibid.

${ }^{57}$ Some scholars have concluded that the publisher printed several of Kant's arguments in the wrong order. See KANT, supra note 1, at pp. xxxii-iv. (translator's note on the text) Moreover, Kant reportedly refused to help his publishers edit this work for a subsequent edition because he felt too consumed by other projects. Ibid. 
ways in which actions can be right. An action is right in one way insofar as it is not civilly wrong, and it is right in quite a different way insofar as it is not criminally wrong.

\section{Conclusion}

There are several reasons to believe that the best interpretation of the Universal Principle of Right tracks the two ways in which actions can be legally wrong. My proposed account makes more sense out of Kant's awkward text than do competing interpretations. More importantly, it integrates and reflects Kant's important philosophical commitments elsewhere concerning these two types of wrongdoing and his claim that some formal wrongs do not wrong anyone in particular.

Moreover, the proposed interpretation reveals the Universal Principle of Right to be a robust formulation dual standards for civil and criminal wrongdoing in the context of traditional legal doctrines. This account both explains and justifies the law's treatment of criminal attempts as crimes in and of themselves, the distinction that the law traditionally makes between ordinary negligence on one hand and reckless endangerment on the other, and traditional differences between civil remedies and criminal punishments.

So understood, the Universal Principle of Right also yields a plausible and individually interesting Kantian account of the nature of criminal conduct: any action A is formally - and therefore criminally - wrong just in case the legality of actions on A's maxim is incompatible with the concept of a rightful condition. One implication of this account is that it appears to rule out the imposition of criminal punishments for strict liability crimes. When strict liability offenses, like innocent trespass or certain regulatory violations, are committed on irreproachable maxims, they are not formally wrong. Kantians may be constrained to conclude that the incarceration of unintentional wrongdoers is always unjustified.

Any new interpretation of the Universal Principle of Right raises more questions than it immediately resolves. If the wrong-making property of a formally wrong action is in the action's maxim, what are the implications of my proposed standard for doctrinal questions about criminal intent and legal insanity? If maxims pick out actions in our continual stream of activity for evaluation as right or wrong, how must we draw the legal distinction between criminal attempt, on one hand, and mere "preparation" on the other? The Universal Principle of Right as I have interpreted it puts new tools in our hands as we attempt to construct answers to these and other important questions. 